Number 3

\title{
DAYA HAMBAT EKSTRAK DAUN KENIKIR (Cosmos caudatus Kunth.) TERHADAP Staphylococcus aureus
}

\author{
Leka Lutpiatina, Nur Rizqi Amaliah, Ratih Dewi Dwiyanti \\ Jurusan Analis Kesehatan Poltekkes Kemenkes Banjarmasin \\ J1 Mistar Cokrokusumo 4a Banjarbaru \\ e-mail: leka.zns@gmail.com
}

\begin{abstract}
Bacground.Leaf kenikir (Cosmos caudatus Kunth.) Has long exploited the community for consumption and traditional medicine. Leaf thinkers contain phenols, flavonoids, saponins and tannins that act as antibacterials.

Objective.This study aims to determine the minimal inhibitory concentration and minimal concentration of kink leaf extract to Staphylococcus aureus bacteria in vitro.

Methods.This research is true experiment with postest only control group design. Free variable in this research is concentration of leaf extract of kenikir (Cosmos caudatus Kunth.). The dependent variable in this study was Staphylococcus aureus bacteria.

The results of the Minimal Inhibitory Concentrations (MICs) showed turbidity at concentrations of $80 \mathrm{mg} / \mathrm{ml}, 160 \mathrm{mg} / \mathrm{ml}$ and presence of clarity at concentrations of 180 $\mathrm{mg} / \mathrm{ml}, 190 \mathrm{mg} / \mathrm{ml}$ and $200 \mathrm{mg} / \mathrm{ml}$. The results of the Minimum Bactericidal Concentrations (MBCs) obtained the amount of colony at $80 \mathrm{mg} / \mathrm{ml}$ concentration of 60 $\mathrm{CFU} / \mathrm{ml}, 160 \mathrm{mg} / \mathrm{ml}$ of $12 \mathrm{CFU} / \mathrm{ml}, 170 \mathrm{mg} / \mathrm{ml}$ of $3 \mathrm{CFU} / \mathrm{ml}, 190 \mathrm{mg} / \mathrm{ml}$ of $0 \mathrm{CFU} /$ $\mathrm{ml}$ and $200 \mathrm{mg} / \mathrm{ml}$ of $0 \mathrm{CFU} / \mathrm{ml}$.

ConclusionBased on the results of this study it can be concluded that MICs of kenikir leaf extract is $170 \mathrm{mg} / \mathrm{ml}$ and MBCs of kenikir leaf extract is $190 \mathrm{mg} / \mathrm{ml}$. It is suggested to do further research about the effect of leaves extract of aphrodisiac to Staphylococcus aureus bacteria is by using other solvent.
\end{abstract}

Keywords: Cosmos caudatus Kunth, Staphylococcus aureus

\section{Pendahuluan}

Infeksi nosokomial dapat disebabkan oleh mikroorganisme diantaranya adalah Staphylococcus aureus, Pseudomonas aeruginosa, Acinetobacter baumannii, Escherichia coli dan Candida albicans (INICC, 2010). Persentase mikroorganisme yang menyebabkan terjadinya infeksi nosokomial yakni Staphylococcus aureus sebesar 34\%,
Pseudomonas aeruginosa dan Escherichia coli sebesar 32\%,Candida albicans sebesar 10\% dan Acinetobacter baumannii sebesar $7 \%^{1}$.

Staphylococcus aureus merupakan penyebab infeksi nosokomial terbesar yaitu 34\%.Staphylococcus aureus dapat ditemukan pada usap hidung perawat ${ }^{2}$, stetoskop $^{3}$ dan kemungkinan menulari pasien.Selain menimbulkan inf 83 Staphylococcus aureus juga menimbulkan 
Leka Lutpiatina, dkk., Daya Hambat Ekstrak Daun Kenikir (Cosmos caudatus kunth.) Terhadap

keracunan makanan yaitu melalui pangan yang tercemar seperti pada saos pentol jajanan ${ }^{4}$.Staphylococcus aureus telah menunjukkan hasil resisten terhadap beberapa antibiotik, tetapi bakteri ini sensitif terhadap bahan-bahan alam seperti propolis lebah ${ }^{5}$.

Tumbuhan obat diketahui potensial untuk dapat dikembangkan lebih lanjut pada penyakit infeksi, namun masih banyak yang belum dibuktikan aktivitasnya secara ilmiah.Sehingga perkembangan ilmu pengetahuan dalam pengembangan obat alam perlu dilakukan secara berkelanjutan ${ }^{6}$.Penggunaan obat dari bahan alam secara umum dinilai lebih aman dan memiliki efek samping yang relatif kecil dari pada penggunaan obat modern ${ }^{7}$.

Salah satu tumbuhan yang dapat digunakan sebagai obat tradisional adalah kenikir (Cosmos caudatus Kunth.) ${ }^{8}$. Kenikir (Cosmos caudatus Kunth.) merupakan tumbuhan tropis anggota Asteraceae yang berasal dari Amerika Tengah dan sebagian daerah beriklim tropis lainnya. Bagian muda kenikir biasanya digunakan masyarakat sebagai lalapan atau dijadikan makanan pembuka karena memiliki rasa dan aroma yang khas ${ }^{9}$.Daun kenikir mengandung senyawa aktif yaitu fenol, flavonoid, tanin dan saponin yang berfungsi sebagai antibakteri.
Hasil penelitian menunjukkan ekstrak metanol daun kenikir pada konsentrasi $\quad 10 \quad \mathrm{mg} / \mathrm{ml}$ mampu menghambat bakteri Stapyhlococcus aureus sebesar 11,32 mm, Bacillus cereus sebesar $6,43 \mathrm{~mm}$ selain itu juga mampu menghambat bakteri gram negatif Escherichia coli sebesar13,4 mm, Klebsiella pneumonia sebesar $8,3 \mathrm{~mm}$, dan Pseudomonas sebesar 8,2 mm serta dapat menghambat pertumbuhan jamur Mucor sebesar 3,53 $\mathrm{mm}$ dan Candida albicans sebesar $4,16 \mathrm{~mm}^{10}$. Penelitian ini bertujuan untuk mengetahui konsentrasi hambat minimal dan konsentrasi bunuh minimal ekstrak daun kenikir (Cosmos caudatus Kunth.) terhadap Staphylococcus aureus.

\section{Metode}

Jenis penelitian yang digunakan dalam penelitian ini adalah eksperimen sebenarnya (true eksperiment). Rancangan penelitian yang digunakan dalam penelitian ini adalah Postest Only Control Group Design yaitu dengan melakukan pemeriksaan daya hambat dan daya bunuh ekstrak daun kenikir (Cosmos caudatus Kunth.) pada konsentrasi $160 \mathrm{mg} / \mathrm{ml}, 320$ $\mathrm{mg} / \mathrm{ml}, 340 \mathrm{mg} / \mathrm{ml}, 380 \mathrm{mg} / \mathrm{ml}$ dan 400 $\mathrm{mg} / \mathrm{ml}$. Kemudian dibandingkan dengan kelompok kontrol negatif, kontrol positif dan kontrol ekstrak dengan jumlah pengulangan sebanyak 3 kali. 
Bahan yang digunakan dalam penelitian ini adalah daun kenikir yang ada di daerah Banjarbaru. Bagian daun yang digunakan adalah daun muda (daun yang dekat pucuk) dan bebas hama. Variabel bebas dalam penelitian ini adalah konsentrasi ekstrak daun kenikir (Cosmos caudatus Kunth.).Variabel terikat dalam penelitian ini adalah bakteri Staphylococcus aureus.

Uji determinasi tanaman kenikir dilakukan di Laboratorium FMIPA Universitas Lambung Mangkurat. Pembuatan ekstrak daun kenikir dengan cara daun kenikir sebanyak $1 \mathrm{~kg}$ dicuci bersih dan ditiriskan. Keringkan hingga benar-benar kering dengan menggunakan oven pada suhu $60^{\circ} \mathrm{C}$ dan kemudian dihaluskan dengan menggunakan blender selama 2 menit. Serbuk daun dimasukkan ke dalam bejana maserasi dan direndam dengan menggunakan pelarut etanol $70 \%$, perbandingan serbuk dengan ekstrak yaitu 1 : 5. Proses maserasi dilakukan selama 3 x 24 jam, setiap 8 jam dilakukan pengadukan, kemudian filtrat diambil dan ditampung. Ampas daun kenikir dimaserasi kembali dan diulang sebanyak 3 kali dengan pelarut etanol $70 \%$ agar dapat dipastikan zat aktif daun kenikir terekstraksi secara sempurna.Hasil yang diperoleh disaring dengan kertas saring. Filtrat dipekatkan dengan menguapkan etanol menggunakan waterbath suhu $50^{\circ} \mathrm{C}$ hingga terbentuk ekstrak kental atau 1/3 bagian. Ekstrak kental daun kenikir ditimbang seberat $5 \mathrm{~g}$ dan dilarutkan dengan $5 \mathrm{ml}$ pelarut gliserin (konsentrasi $1000 \mathrm{mg} / \mathrm{ml}$ ).Dihomogenkan sampai ekstrak daun kenikir kental terlarut sempurna. Di dalam tabung steril dimasukkan $5 \mathrm{ml}$ ekstrak daun kenikir konsentrasi $1000 \mathrm{mg} / \mathrm{ml}$ ditambah $5 \mathrm{ml}$ aquades steril sehingga diperoleh konsentrasi $500 \mathrm{mg} / \mathrm{ml}$. Membuat deret konsentrasi ekstrak daun kenikir pada masing masing tabung reaksi steril seperti pada tabel berikut:

Tabel 1 Pengenceran konsentrasi

\begin{tabular}{|c|c|c|c|c|}
\hline $\begin{array}{c}\text { Tabung } \\
\text { steril }\end{array}$ & $\begin{array}{c}\text { Larutan } \\
500 \mathrm{mg} / \mathrm{ml}\end{array}$ & $\begin{array}{c}\text { Aquades } \\
\text { Steril }\end{array}$ & $\begin{array}{c}\text { Konsentrasi } \\
\text { awal }(\mathrm{mg} / \mathrm{ml})\end{array}$ & $\begin{array}{c}\text { Konsentrasi setelah ditambah } \\
\text { suspensi bakteri 1:1(mg/ml) }\end{array}$ \\
\hline 1 & $3,2 \mathrm{ml}$ & $0,8 \mathrm{ml}$ & 400 & 200 \\
\hline 2 & $3,04 \mathrm{ml}$ & $0,96 \mathrm{ml}$ & 380 & 190 \\
\hline 3 & $2,72 \mathrm{ml}$ & $1,28 \mathrm{ml}$ & 340 & 170 \\
\hline 4 & $2,56 \mathrm{ml}$ & $1,44 \mathrm{ml}$ & 320 & 80 \\
\hline 5 & $1,28 \mathrm{ml}$ & $2,72 \mathrm{ml}$ & 160 & \\
\hline
\end{tabular}

Penentuan Konsentrasi Hambat Minimal

(KHM) dengan caraKonsentrasi 200 $\mathrm{mg} / \mathrm{ml}=$ diambil $1 \mathrm{ml}$ dari tabung konsentrasi $400 \mathrm{mg} / \mathrm{ml}$ ekstrak daun kenikir dan ditambah $1 \mathrm{ml}$ suspensi bakteri di dalam TSB. Lakukan 
Leka Lutpiatina, dkk., Daya Hambat Ekstrak Daun Kenikir (Cosmos caudatus kunth.) Terhadap Staphylococcus aureus

pengulangan sebanyak 3 kali.

Konsentrasi $190 \mathrm{mg} / \mathrm{ml}=$ diambil $1 \mathrm{ml}$ dari tabung konsentrasi $380 \mathrm{mg} / \mathrm{ml}$ ekstrak daun kenikir dan ditambah $1 \mathrm{ml}$ suspensi bakteri di dalam TSB. Lakukan pengulangan sebanyak 3 kali.Konsentrasi $170 \mathrm{mg} / \mathrm{ml}=$ diambil $1 \mathrm{ml}$ dari tabung konsentrasi $340 \mathrm{mg} / \mathrm{ml}$ ekstrak daun kenikir dan ditambah $1 \mathrm{ml}$ suspensi bakteri di dalam TSB. Lakukan pengulangan sebanyak 3 kali. Konsentrasi $160 \mathrm{mg} / \mathrm{ml}=$ diambil $1 \mathrm{ml}$ dari tabung konsentrasi $320 \mathrm{mg} / \mathrm{ml}$ ekstrak daun kenikir dan ditambah $1 \mathrm{ml}$ suspensi bakteri di dalam TSB. Lakukan pengulangan sebanyak 3 kali. Konsentrasi $80 \mathrm{mg} / \mathrm{ml}=$ diambil $1 \mathrm{ml}$ dari tabung konsentrasi $160 \mathrm{mg} / \mathrm{ml}$ ekstrak daun kenikir dan ditambah $1 \mathrm{ml}$ suspensi bakteri di dalam TSB. Lakukan pengulangan sebanyak 3 kali.Tabung kontrol positif diisi dengan suspensi antibakteri kloramfenikol dan TSB steril sebanyak $1 \mathrm{ml}$ kemudian ditambah dengan $1 \mathrm{ml}$ suspensi bakteri di dalam TSB.Lakukan pengulangan sebanyak 3 kali.Tabung kontrol negatif diisi dengan $1 \mathrm{ml}$ TSB steril ditambah $1 \mathrm{ml}$ suspensi bakteri di dalam TSB.Lakukan pengulangan sebanyak 3 kali.Tabung kontrol ekstrak daun kenikir diisi dengan $1 \mathrm{ml}$ ekstrak daun kenikir ditambah $1 \mathrm{ml}$ TSB steril.Lakukan pengulangan sebanyak 3 kali. Dicampur baik-baik dan diinkubasi selama 24 jam pada suhu $37^{\circ} \mathrm{C}$

di dalam inkubator. Dibaca hasilnya dengan mencari tabung yang mengandung kadar ekstrak terendah tetapi masih mampu menghambat bakteri (larutan jernih) yang dinyatakan sebagai Konsentrasi Hambat Minimal (KHM). Hasil divisualisasikan dalam bentuk tabel. Setelah diperoleh hasil konsentrasi hambat minimal, pemeriksaan dilanjutkan dengan penentuan Konsentrasi Bunuh Minimal (KBM) ${ }^{11}$.

Penentuan Konsentrasi Bunuh Minimal (KBM) dengan cara tabung yang telah diinkubasi selama 24 jam pada suhu $37^{\circ} \mathrm{C}$ dan diamati tingkat kekeruhannya untuk melihat KHM yaitu sampai didapatkan tabung yang mengandung kadar ekstrak terendah tetapi masih mampu menghambat bakteri (larutan jernih) kemudian dilakukan penanaman pada media nutrient agar (NA) untuk melihat Konsentrasi Bunuh Minimal (KBM). Sebanyak 5 ul larutan diambil dari masing-masing konsentrasi kemudian diratakan pada permukaan media Nutrient Agar (NA) dengan menggunakan batang penyebar. Diinkubasi selama 24 jam pada suhu $37^{\circ} \mathrm{C}$ di dalam inkubator. Dibaca hasil dengan menghitung jumlah koloni yang tumbuh pada permukaan media dengan menggunakan colony counter kemudian dicari konsentrasi yang sama sekali tidak menunjukkan pertumbi 86 bakteri.Lakukan penentuan tersebut 
Leka Lutpiatina, dkk., Daya Hambat Ekstrak Daun Kenikir (Cosmos caudatus kunth.) Terhadap Staphylococcus aureus

dengan 3 kali pengulangan. Data yang

diperoleh dari hasil penentuan daun kenikir terhadap pertumbuhan konsentrasi hambat minimal (KHM) dan penentuan konsentrasi bunuh minimal (KBM) dianalisis secara deskriptif ${ }^{11}$. Staphylococcus aureus memperlihatkan adanya tingkat kejernihan pada penentuan Konsentrasi Hambat Minimal (KHM) yang dapat dilihat pada tabel

Hasil sebagai berikut.

Tabel 2 Hasil Konsentrasi Hambat Minimal (KHM)

\begin{tabular}{|c|c|c|c|c|}
\hline \multirow{2}{*}{$\begin{array}{c}\text { Konsentrasi ekstrak daun } \\
\text { kenikir }\end{array}$} & \multicolumn{3}{|c|}{ Kejernihan } & Kesimpulan \\
\cline { 2 - 5 } & I & II & III & \\
\hline $80 \mathrm{mg} / \mathrm{ml}$ & Keruh & Keruh & Keruh & Keruh \\
\hline $160 \mathrm{mg} / \mathrm{ml}$ & Keruh & Keruh & Keruh & Keruh \\
\hline $170 \mathrm{mg} / \mathrm{ml}$ & Jernih & Jernih & Jernih & Jernih \\
\hline $190 \mathrm{mg} / \mathrm{ml}$ & Jernih & Jernih & Jernih & Jernih \\
\hline $200 \mathrm{mg} / \mathrm{ml}$ & Jernih & Jernih & Jernih & Jernih \\
\hline $\mathrm{K}(+)$ & Jernih & Jernih & Jernih & Jernih \\
\hline $\mathrm{K} \mathrm{(-)}$ & Keruh & Keruh & Keruh & Keruh \\
\hline
\end{tabular}

Berdasarkan penentuan Konsentrasi Bunuh Minimal (KBM) diperoleh adanya pertumbuhan jumlah koloni yang dapat dapat dilihat pada tabel 2 sebagai berikut. Tabel 3 Hasil Konsentrasi Bunuh Minimal (KBM)

\begin{tabular}{|c|c|c|c|c|}
\hline \multirow{2}{*}{$\begin{array}{c}\text { Konsentrasi ekstrak daun } \\
\text { Kenikir }\end{array}$} & \multicolumn{3}{|c|}{$\begin{array}{c}\text { Jumlah koloni (CFU/ml) pada } \\
\text { Ulangan }\end{array}$} & \multirow{2}{*}{ Rata-rata } \\
\cline { 2 - 4 } & I & II & III & \\
\hline $80 \mathrm{mg} / \mathrm{ml}$ & 35 & 20 & 5 & 20 \\
\hline $160 \mathrm{mg} / \mathrm{ml}$ & 10 & 1 & 2 & 4 \\
\hline $170 \mathrm{mg} / \mathrm{ml}$ & 1 & 0 & 2 & 1 \\
\hline $190 \mathrm{mg} / \mathrm{ml}$ & 0 & 0 & 0 & 0 \\
\hline $200 \mathrm{mg} / \mathrm{ml}$ & 0 & 0 & 0 & 0 \\
\hline $\mathrm{K}(+)$ & 0 & 0 & 0 & 0 \\
\hline $\mathrm{K}(-)$ & 1440 & 1120 & 1400 & 1320 \\
\hline
\end{tabular}

Hasil rata-rata jumlah koloni tiap konsentrasi pada penentuan konsentrasi bunuh minimal disajikan seperti pada gambar 1. 
Gambar 1 Grafik Rata-rata Jumlah Koloni Staphylococcus aureus Berbagai Konsentrasi pada Penentuan Konsentrasi Bunuh Minimal

$(\mathrm{KBM})$

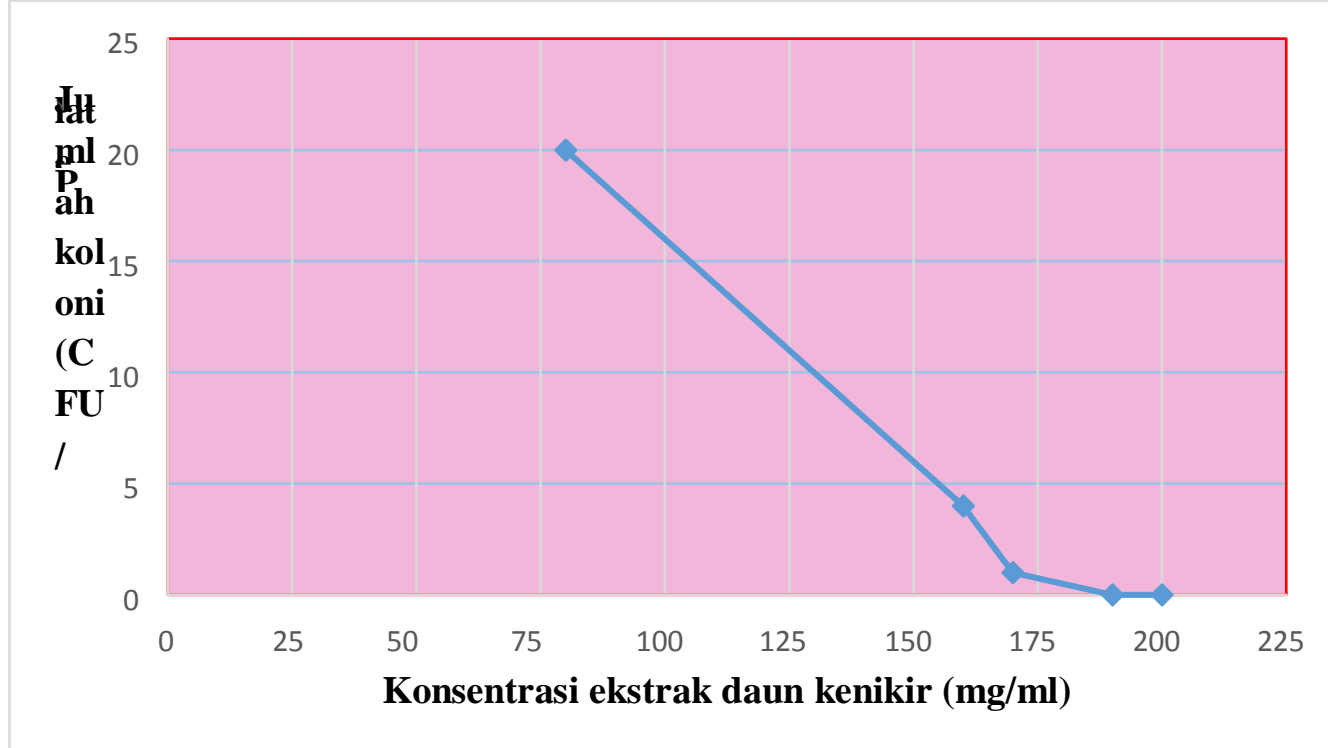

Berdasarkan hasil konsentrasi hambat minimal dengan pengamatan secara visual menunjukkan kekeruhan dimulai dari konsentrasi $80 \mathrm{mg} / \mathrm{ml}$ sampai konsentrasi $160 \mathrm{mg} / \mathrm{ml}$ dan menunjukkan kejernihan dimulai dari konsentrasi $\quad 170 \quad \mathrm{mg} / \mathrm{ml}$ sampai konsentrasi 200 mg/ml. Hasil konsentrasi bunuh minimal diperoleh adanya penurunan jumlah koloni pada pemberian berbagai konsentrasi ekstrak daun kenikir. Pertumbuhan jumlah koloni terbesar terjadi pada konsentrasi 80 $\mathrm{mg} / \mathrm{ml}$ dengan jumlah koloni sebanyak 60 koloni dan pertumbuhan koloni terkecil terjadi pada konsentrasi 190 $\mathrm{mg} / \mathrm{ml}$ dengan jumlah koloni sebanyak 0 koloni.

\section{Pembahasan}

Daun kenikir merupakan salah satu sayuran yang sering dikonsumsi masyarakat Indonesia, selain itu daun kenikir memiliki manfaat sebagai bahan obat.Kandungan senyawa aktif pada daun kenikir berupa flavonoid, saponin, terpenoid, alkaloid, tanin dan minyak atsiri yang berpotensi sebagai antibakteri $^{12}$.

Konsentrasi hambat minimal digunakan untuk menentukan konsentrasi terkecil yang masih dapat menghambat pertumbuhan bakeri.Penentuan KHM perlu dilakukan untuk melihat kekuatan dan sensitivitas suatu zat antibiotic. Konsentrasi Hambat Minimal (KHM) terjadi pada konsentrasi 170 $\mathrm{mg} / \mathrm{ml}$.Selain memiliki kemampuan dalam menghambat pertumbuhan 
Leka Lutpiatina, dkk., Daya Hambat Ekstrak Daun Kenikir (Cosmos caudatus kunth.) Terhadap

Staphylococcus aureus

Staphylococcus aureus, daun kenikir juga memiliki kemampuan dalam membunuh

Staphylococcus aureus. Konsentrasi

Bunuh Minimal (KBM) terjadi pada konsentrasi $190 \mathrm{mg} / \mathrm{ml}$ dimana pada konsentrasi tersebut tidak ditemukan adanya pertumbuhan koloni Staphylococcus aureus.Penelitian ini memperoleh hasil KHM dan KBM diatas konsentrasi $100 \%$, tanaman obat lain seperti Binahong juga menghasilkan zone resisten $(11 \mathrm{~mm})$ terhadap Salmonella typhi ${ }^{13}$.

Hasil penelitian menunjukkan bahwa semakin tinggi tingkat konsentrasi ekstrak daun kenikir yang ditambahkan, semakin besar pula kemampuan daya hambat dan daya bunuh ekstrak daun kenikir terhadap pertumbuhan Staphylococcus aureus.Hal ini ditandai dengan terjadinya kejernihan pada media TSB uji dilusi tabung dan penurunan jumlah koloni Staphylococcus aureus yang tumbuh pada permukaan media nutrient agar.

Daya antibakteri daun kenikir dikarenakan adanya senyawa aktif yaitu fenol, flavonoid, saponin dan $\operatorname{tanin}^{10}$, Daun kenikir mengandung senyawa saponin, flavonoid, polifenol, dan minyak atsiri.Flavonoid yang terdapat dalam kenikir merupakan zat yang berfungsi sebagai antibakteri. Flavonoid menghambat fungsi membran sel dengan cara membentuk senyawa kompleks yang berikatan dengan protein. Hal ini menyebabkan rusaknya membran sel bakteri yang selanjutnya diikuti dengan keluarnya senyawa intraselular ${ }^{14}$.Selain flavonoid yang terdapat dalam kenikir yang juga bisa berfungsi sebagai antibakteri yaitu tanin.Senyawa tanin mampu mengganggu membran plasma dan menghambat kerja enzim ${ }^{15}$. Penghambatan kerja enzim berkaitan dengan metabolisme bakteri yang akan berpengaruh terhadap pertumbuhan bakteri.

Penelitian tentang Uji Aktivitas Antibakteri Daun Kenikir (Cosmos caudatus Kunth.) dan Daun Sintrong (Crassocephalum crepidioides (Benth.) S. Moore) terhadap bakteri Staphylococcus aureus dan Pseudomonas aeruginosa diperolehKonsentrasi Hambat Minimal (KHM) terhadap bakteri Staphylococcus aureus dari ekstrak etil asetat daun kenikir (Cosmos caudatus Kunth.) adalah pada konsentrasi 7.000 ppm atau sama dengan $7 \mathrm{mg} / \mathrm{ml}^{16}$. Adanya perbedaan hasil penelitian antara peneliti dengan peneliti lain ini dapat disebabkan oleh pelarut yang digunakan. Hal ini dimungkinkan karena golongan senyawa yang berpotensi sebagai antibakteri pada daun kenikir lebih banyak tersari dalam etil asetat dibandingkan dengan etanol 70\%. Dilihat dari sifatnya etil asetat merupakan pelarut yang volatil dan mudah terbakar, 
Leka Lutpiatina, dkk., Daya Hambat Ekstrak Daun Kenikir (Cosmos caudatus kunth.) Terhadap

Staphylococcus aureus

sehingga dalam penguapannya tanpa

terhadap Staphylococcus aureus dengan

pemanasan, sedangkan etanol proses

menggunakan pelarut n-heksana

penguapannya dengan pemanasan. Proses

pemanasan inilah yang memungkinkan

menjadi salah satu faktor perbedaan

jumlah kandungan golongan senyawa

yang memiliki aktivitas antibakteri dalam

ekstrak tersebut, sehingga konsentrasi

hambat minimal yang diperoleh juga

berbeda. Pada penguapan ekstrak etanol

terdapat pemanasan yang dimungkinkan

menyebabkan rusaknya senyawa-

senyawa yang sebenarnya memiliki

aktivitas antibakteri, sedangkan pada

penguapan ekstrak etil asetat dilakukan

tanpa pemanasan dan rusaknya senyawa

karena pemanasan dapat dihindari ${ }^{16}$.

\section{Kesimpulan}

Konsentrasi hambat minimal ekstrak daun kenikir (Cosmos caudatus Kunth.) terhadap Staphylococcus aureus terjadi pada konsentrasi $170 \mathrm{mg} / \mathrm{ml}$. Konsentrasi bunuh minimal ekstrak ekstrak daun kenikir (Cosmos caudatus Kunth.) terhadap Staphylococcus aureus terjadi pada konsentrasi 190 mg/ml.

\section{Saran}

Perlu penelitian lebih lanjut mengenai konsentrasi hambat minimal dan konsentrasi bunuh minimal ekstrak daun kenikir (Cosmos caudatus Kunth.)

\section{Daftar Pustaka}

1) Tortora et al, 2001. Device-Associated Infection Rate and Mortality in Intensive Care Units of World: Findings of the Internasional Nosokomial Infektions Control Consortium. Infect Control Hosp Epidemiol; 27(4). Hal: $349-56$

2) R. D. Dwiyanti, A. Muhlisin, and A. Muntaha, 2015. MRSA dan VRSA pada Paramedis RSUD Ratu Zalecha Martapura, Med. Lab. Technol. J., vol. 1, no. 1, pp. 2733.

3) L. Lutpiatina, 2017. Cemaran Staphylococcus aureus dan Pseudomonas aerogenosa Pada Stetoskop dirumah sakit. Jurnal Teknologi Laboratorium, vol. 6, no.2, pp.

4) R. D. Dwiyanti and L. Lutpiatina, 2016. Mutu Bakteriologis Saus Tomat Pentol Di Banjarbaru, Med. Lab. Tecnol. J., vol. 2, no. 1, pp. 1-5,

5) L. Lutpiatina, 2015. Efektivitas Ektrak Propolis Lebah Kelulut (Trigona spp) Dalam Menghambat Pertumbuhan Salmonella typhi, Staphylococcus aureus dan Candida albicans, J. Skala Kesahatan, vol. 6, no. 1

6) Hertiani T., Palupi, I.S.,Sanliferianti, Nurwindasari, H.D. 2003. Uji Potensial Antimikroba terhadap S. aureus, E. coli, Shigella dysentriae, dan Candida albicans dari Beberapa Tanaman Obat Tadisional untuk Penyakit Infeksi. Pharmacon.

7) Yanti Y. Warbung, 2013, Daya Hambat Ekstrak Spons Laut Callyspongia sp terhadap Pertubuhan Bakteri Staphylococcus aureus, jurnal e-GiGi, vol. 1, no.2

8) Saranraj, P. And S.Sivasakthi, 2014. Medicinal Plants and its Antimicrobial Properties: a Review. Global Journal of Pharmacology

9) Shui, G., Leong, L.P., Shih, P.W. 2005.R. ' screening and characterization 90 antioxidants of Cosmos Caudatus using liquid chromatography coupled with mass spectrometry. J.Chromatogr. B Anal.Tech. Biomed. Life Sci . 827, 127 - 138.

10) Daulat, Patil G. dan Nikam Shashikant V. 2013. In Vitro Antimicrobial, Antioxidant Activity, and Phytochemical Analysis of Cosmos caudatus (Wild Cosmos).

11) Annisa Rahmi, Erfan Roebiakto, Leka Lutpiatina, 2016, Potensi Ekstrak Rimpang Kencur (Kaempferia galanga L.) Menghambat PertumbuhanCandida albicans, 
Leka Lutpiatina, dkk., Daya Hambat Ekstrak Daun Kenikir (Cosmos caudatus kunth.) Terhadap Staphylococcus aureus

Med. Lab. Technol. J., vol.2, no.2, pp.70-76

12) Ratih Dewi Dwiyanti, Nurlailah, Indah Kurnia Widiningsih, 2015. Efektivitas air rebusan daun binahong(Anredera cordifolia) terhadap pertumbuhanSalmonella typhi, Med. Lab. Tecnol. J., vol. 1, no. 1, pp.1-6

13) Dwiyanti, Wariska., Muslimin Ibrahim, Guntur Trimulyono. 2014. Pengaruh Ekstrak Daun Kenikir (Cosmos caudatus) terhadap pertumbuhan Bakteri Bacillus cereus secara In Vitro. Ejournal unesa

14) Rijayanti, Rika Pratiwi. 2014. Uji Aktivitas Antibakteri Ekstrak Etanol Daun Mangga Bacang (mangifera foetida L.) terhadap Staphylococcus aurus Secara In Vitro. Jurnal untan

15) Nuria, Maulita Cut., Arvin Faizatun, Sumantri. 2009. Uji Aktivitas Antibakeri
Ekstrak Etanol Daun Jarak Pagar (Jantrophacurcas L.) Terhadap Bakteri Staphylococcus aureus ATCC 25923, Escherichia coli ATCC 25922 dan Salmonella typhi ATCC 1408. Jurnal ilmuilmu Pertanian.

16) Gaty Safita, Endah Rismawati Eka Sakti, Livia Syafnir, 2015, Uji Aktivitas Antibakteri Daun Kenikir (Cosmos caudatus Kunth.) dan Daun Sintrong (Crassocephalum crepidioides (Benth.) S. Moore.) terhadap Bakteri Staphylococcus aureus dan Pseudomonas aeruginosa,Prosiding Penelitian SPeSIA Unisba, pp.421-428 